J. Perinat. Med. 17 (1989) 433

\section{Studies of normal and prematurely ruptured human amniotic mem- branes: Low calcium and magnesium in prematurely ruptured mem- branes}

\author{
Gideon Kidroni' ${ }^{1}$, Simcha Yagel $^{2}$, Jacob Menczel $^{1}$, and Moshe Ron ${ }^{2}$ \\ ${ }^{1}$ Research Laboratory, Department of Internal Medicine and ${ }^{2}$ The Department \\ of Obstetrics and Gynecology, Hadassah University Hospital, Mount Scopus, \\ Jerusalem, Israel
}

\section{Introduction}

Premature rupture of fetal membranes (PROM) occurs in approximately $10 \%$ of all pregnancies [18]. This common complication is one of the major causes of premature deliveries and is causally related to perinatal mortality and morbidity [19].

Considerable information has been gathered to date concerning the mechanical strength [2], viscoelastic properties [22] and structural and ultrastructural elements [15] [27] of the amniotic membrane. Among the chemical components investigated in amniotic membranes were the collagen and glycosaminoglycans $[29,30]$ prolactin [25] and various enzymes [12, 26].

Chorioamnionitis may play an important role in causing PROM in about $33 \%$ of the cases [24] though in many cases it may be the result of PROM rather than its cause [19, 23].

Despite the above information, the etiology and mechanisms responsible for the occurrence of PROM are not yet clearly understood in most cases. In the present study, both normal amniotic membranes and prematurely ruptured membranes were analyzed for a variety of structural and cellular markers, in an attempt to find some indicators for changes which may possibly contribute to PROM.

\section{Patients and methods}

This study included ten women with PROM and ten matched controls between 37 to 40 weeks of a normal first pregnancy. Premature rupture of

\section{Curriculum vitae}

Dr. GIDEON KIDRONI was born in Vienna in 1935. He studied for his M.Sc. in Microbiology and Chemistry and Ph. D. in Biochemistry at the Hebrew University Hadassah Medical School in Jerusalem. He served as a research fellow at the Department of Biochemistry at the Al-

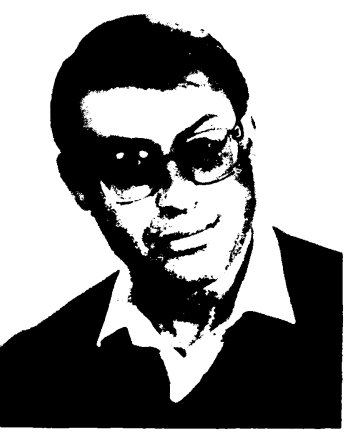
bert Einstein Medical Center in Philadelphia from 1971 to 1973, where he studied glycoproteins of the gram negative bacterial envelope. He spent the years 19731976 as a research fellow at the Elliott P. Joslin Research Laboratory, Department of Biological Chemistry, Harvard Medical School in Boston, where he worked on cell membrane glycoproteins of the thyroid gland. From 1977 to 1988 he was in charge of the Research Laboratory, Department of Internal Medicine, Hadassah University Hospital, Mount Scopus, Jerusalem which specialized in Calcium metabolism and Vitamin $D_{3}$ hormonal system. Since 1988 he is product manager at RAD Chemicals Ltd, Kiryat Weizman Science based Industrial Park, Rehovot, Israel.

the membranes was defined as a spontaneous clinically unquestionable rupture of the membranes which occured at least two hours before onset of uterine contractions. Only first pregnancies were entered into the study in order to exclude possible mechanical cervical factors which may be caused by previous abortions or deliveries and which could have an effect on 
PROM. The mean week of delivery in the PROM group was $38 \pm 1.3$ weeks and for the control group $38.5 \pm 0.8$ weeks of gestation. Seven of the PROM group patients started a spontaneous labor within 12 hours from admission and three recieved oxytocin infusion when labor did not start after 12 hours. The mean length of time from rupture of the membranes to delivery was $18.7 \pm 5.2$ hours.

For each PROM case the control case was the next woman who came to the delivery room in spontaneous labor, at the same age group (5 years interval), and in the same gestational week of a normal pregnancy. The mean duration of labor in the control group was $8.3 \pm 2.1$ hours; non of them recieved oxytocin. Non of the women in both groups showed any signs of amnionitis.

Preparation of tissue homogenates: Amniotic membrane samples were frozen under liquid nitrogen. The frozen tissue was ground thoroughly to fine powder with a mortar and pestle and suspended in double distilled water.

Chemical analyses: All analyses were carried out in duplicates. Calcium and magnesium analyses were carried out in quadruplicate. In each analysis appropriate standards (hexoses, hexosamines, sialic acid) and proteins of known structure (e.g. Fetuin) were carried through the whole procedure to determine recoveries. Details of most of the methods used in this study have been outlined previously [13].

Protein was determined according to LOWRY [17]. Total neutral sugars were determined after hydrolysis and work up [13] by the Anthrone reaction [31] and by the Park-Johnson ferricyanide method [21]. Hexosamines were determined, after hydrolysis [13] by the ELSON-MORGAN reaction [3] while sialic acid was determined by the thiobarbituric acid reaction [34]. Total sialic acid was determined with the resorcinol reagent [33]. Uronic acids were analyzed after hydrolysis (1N $\mathrm{HCl}$, six hours, $100^{\circ} \mathrm{C}$ ) and passage thourgh Dowex 50 and Dowex 1 columns [32] by the carbazole procedure [10]. Controls for hexose contribution to the absorbance (Fetuin + hexoses) and for recovery corrections (glucuronic acid standards and chondroitin sulfate-Sigma) were included.

Lipids were extracted by the FoLCH procedure [11] and analyzed for cholesterol [35] and phosphorus according to CHEN et al [7]. Phospholipid content was obtained by multiplying the phosphorus weight by a factor of 25 [13] DNA was determined by the diphenylamine reaction [6] and RNA with the Orcinol method [5].

\section{Results}

Both groups of amniotic membranes contained considerable and similar amounts of carbohydrates (table I). These gross analyses were not indicative of any major structural differences between prematurely ruptured and normal amniotic membranes. Neither did the analysis of DNA and RNA yield any evidence of some striking differences in the cellular components between both groups, nor were any significant differences found by the analyses of their lipid fractions (table II).

Table I. Carbohydrate composition ${ }^{\mathrm{b}}$ of normal amniotic membrnaes and PRM ${ }^{\mathrm{a}}$

\begin{tabular}{|c|c|c|c|c|c|c|}
\hline \multirow{3}{*}{ Membrane } & \multicolumn{6}{|c|}{ (mg/100 mg membrane protein) } \\
\hline & \multicolumn{2}{|l|}{ Neutral sugars } & \multicolumn{2}{|l|}{ Sialic acid } & \multirow[t]{2}{*}{ Uronic acid ${ }^{\mathrm{c}}$} & \multirow{2}{*}{$\begin{array}{l}\text { Hexos- } \\
\text { amines }^{d}\end{array}$} \\
\hline & $\begin{array}{l}\text { Park-Johnson } \\
\text { method }\end{array}$ & $\begin{array}{l}\text { Anthrone } \\
\text { method }\end{array}$ & $\begin{array}{l}\text { Thiobarbituric } \\
\text { acid method }\end{array}$ & $\begin{array}{l}\text { Resorcinol } \\
\text { method }\end{array}$ & & \\
\hline Normal & $\begin{array}{l}15.2 \pm 5.4 \\
(6)\end{array}$ & $\begin{array}{l}12.6 \pm 7.3 \\
(6)\end{array}$ & $\begin{array}{l}1.5 \pm 0.6 \\
(7)\end{array}$ & $\begin{array}{l}1.6 \pm 0.3 \\
(7)\end{array}$ & $\begin{array}{l}2.7 \pm 1.3 \\
(7)\end{array}$ & $\begin{array}{l}6.5 \pm 1.7 \\
(7)\end{array}$ \\
\hline PRM & $\begin{array}{l}15.4 \pm 8.3 \\
(10)\end{array}$ & $\begin{array}{l}12.7 \pm 3.9 \\
(10)\end{array}$ & $\begin{array}{l}1.6 \pm 0.4 \\
(10)\end{array}$ & $\begin{array}{l}1.6 \pm 0.5 \\
(10)\end{array}$ & $\begin{array}{l}2.2 \pm 1.2 \\
(10)\end{array}$ & $\begin{array}{l}6.6 \pm 3.0 \\
(10)\end{array}$ \\
\hline
\end{tabular}

$a=$ Numbers in parentheses denote number of membranes analyzed

$\mathrm{b}=$ Monomer weights

c $=$ Calculated as glucouronic acid

$\mathrm{d}=$ Presumed to be present in the $\mathrm{N}$-accetylated form 
Table II. Nucleic acids, cholesterol and phospholipid composition of normal amniotic membrnaes and PRM

\begin{tabular}{|c|c|c|c|c|c|}
\hline \multirow[b]{2}{*}{ Membrane } & \multicolumn{5}{|c|}{ (mg/100 mg membrane protein) } \\
\hline & DNA & RNA & Cholesterol & $\begin{array}{l}\text { Lipid } \\
\text { phosphorus }\end{array}$ & Phospholipids ${ }^{\mathrm{b}}$ \\
\hline Normal & $\begin{array}{l}0.73 \pm 0.22 \\
(7)\end{array}$ & $\begin{array}{l}3.68 \pm 0.82 \\
(7)\end{array}$ & $\begin{array}{l}1.82 \pm 0.58 \\
(7)\end{array}$ & $\begin{array}{l}0.29 \pm 0.15 \\
(7)\end{array}$ & $\begin{array}{l}7.2 \pm 3.6 \\
(7)\end{array}$ \\
\hline PRM & $\begin{array}{l}0.66 \pm 0.27 \\
(10)\end{array}$ & $\begin{array}{l}3.82 \pm 1.63 \\
(10)\end{array}$ & $\begin{array}{l}1.68 \pm 0.64 \\
\text { (9) }\end{array}$ & $\begin{array}{l}0.24 \pm 0.10 \\
(9)\end{array}$ & $\begin{array}{l}6.0 \pm 2.4 \\
(9)\end{array}$ \\
\hline
\end{tabular}

$a=$ Numbers in parentheses denote number of membranes analyzed

$\mathrm{b}=$ Calculated by multiplying the phosphorous weight by a factor of 25 (KIDRONI et al., 1980)

Table III. Electrolytes composition of normal amniotic membranes and PRM ${ }^{\mathrm{a}}$

\begin{tabular}{|c|c|c|c|c|}
\hline \multirow[b]{2}{*}{ Membrane } & \multicolumn{4}{|c|}{ (mg/100 mg membrane protein) } \\
\hline & Calcium & Magnesium & Sodium & Potassium \\
\hline Normal & $\begin{array}{l}0.32 \pm 0.07^{b} \\
(10)\end{array}$ & $\begin{array}{l}0.30 \pm 0.19^{d} \\
(10)\end{array}$ & $\begin{array}{l}0.58 \pm 7.05 \\
(7)\end{array}$ & $\begin{array}{l}1.37+.0 .54 \\
(7)\end{array}$ \\
\hline PRM & $\begin{array}{l}0.24 \pm 0.07^{\mathrm{c}} \\
(10)\end{array}$ & $\begin{array}{l}0.15 \pm 0.04^{e} \\
(10)\end{array}$ & $\begin{array}{l}4.49 \pm 3.95 \\
(10)\end{array}$ & $\begin{array}{l}1.16 \pm 0.71 \\
(10)\end{array}$ \\
\hline
\end{tabular}

$a=$ Numbers in parentheses denote number of membranes analyzed

$\mathrm{b}-\mathrm{e}=$ Statistically significant differences

For both calcium and magnesium data $\mathrm{p}<0.05$

The considerable variance of sodium and potassium in the membranes from both groups rendered the observed differences statistically insignificant (table III).

Apparently, despite the precautions and rinsing in Tris- $\mathrm{NaCl}$ buffer, contamination of the membranes by these common elements was not avoided during post partum handling. On the other hand, the analysis of calcium and magnesium content of the amniotic membranes showed a statistically significant $(\mathrm{p}<0.05)$ membranes showed a statistically significant $(\mathrm{p}<0.05)$ lower concentration of both elements in the prematurely ruptured membranes as compared with the normal controls (table III).

\section{Discussion}

The present study compared normal amniotic membranes obtained at term with membranes of the same gestational age which were ruptured prior to onset of uterine contractions, thus fulfilling the criterion of PROM. Findings from such membranes may, therefore, be relevant to the understanding of the PROM phenomenon. Studies of these membranes also have the advantage of a direct comparison with normal amniotic membranes of equal gestational age. The study of prematurely ruptured amniotic membranes from preterm deliveries is, however, hampered due to the scarcity of normal preterm membranes as gestational age matched normal controls. The need exists for gestational age matched control membranes in these studies, since age related changes occur in this tissue, such as the decrease of collagen and glycosaminoglycans content in normal membranes as a function of increased gestational age $[29,30]$.

Carbohydrates analysis of normal and prematurely ruptured amniotic membranes has not produced any major differences which may have been indicative of alterations in glycoproteins, glycosaminoglycans or glycolipids in PROM, inconsistent with some reports $[29,30]$. This, however, does not exclude the possibility that some changes do occur in these components in PROM 
without affecting, significantly, the gross analysis of carbohydrates.

The similar amounts of DNA and RNA in both groups of membranes suggest that the number of cells in prematurely ruptured membranes is similar to that found in the normal amniotic membranes. Thus, cell degeneration noted in ruptured areas $[12,4]$ may be limited to a rather small section of the tissue and may, perhaps, be attributed to certain cases of local infections [19, 23]. The concentration of the cellular components, like cholesterol and phospho-lipids, were also not significantly different in the two groups of membranes, consistent with the DNA and RNA data.

Contrary to the other data, statistically significant lower concentrations of calcium and magnesium were found in the prematurely ruptured membranes as compared with the controls. Direct evidence implicating calcium and magnesium with PROM has not, as yet, been forwarded. Recently, lower than normal maternal serum calcium levels were reported in women with preterm delivery [14]. Empiric treatment with magnesium was found to decrease the in- cidences of PROM in pregnancies with a high risk of this complication [9].

In the present study no distinction was made between intracellular and extracellular calcium and magnesium of the amniotic membranes. Both elements, whether intra or extra cellular have important biological functions [8]. Therefore, a more detailed understanding of the possible effect of lowered levels of these elements on important functions of the amnion requires further studies. Various metabolic functions of the amniotic cells have been described. These cells may have absorptive capacities secretion of compounds like lipids and phospholipids [27], and prostaglandins [20]. Cyclic AMP synthesis in these cells is hormonally regulated [16] and they posses a very active-generating metabolism [28]. In view of the varied metabolic roles of calcium and magnesium [1], further investigation of the effect of lower concentrations of these elements in the amniotic membranes, which ruptured premaurely, is warranted. Furhtermore, these studies may also lead to possible treatment schedules [9] for pregnant women who have recurrent PROM problems, or pregnant women at higher risk of PROM.

\begin{abstract}
Prematurely ruptured amniotic membranes at term, and membranes from normal term pregnancies were studied. The membranes were analyzed for neutral sugars, hexosamines, sialic acid, uronic acid, DNA, RNA, cholesterol, phospholipids, calcium, magnesium, sodium and potassium. The only significant difference found between the normal and the prematurely ruptured membranes was a significantly lower concen-
\end{abstract}

tration of calcium and magnesium in the latter group. (Calcium $0.32 \pm 0.07$, vs. $0.24 \pm 0.07$, p $<0.05$; Magnesium $0.30 \pm 0.19$ vs. $0.15 \pm 0.04, \mathrm{p}<0.05$; in $\mathrm{mg} /$ $100 \mathrm{mg}$ protein). The possible metabolic effects of low calcium and magnesium may be of relevance to the pathogenesis of premature rupture of the amniotic membranes.

Keywords: Amniotic membrane, calcium, magnesium, premature rupture.

\section{Zusammenfassung}

Untersuchungen an normalen und vorzeitig rupturierten Amnionmembranen beim Menschen: niedriges Calzium und Magnesium in vorzeitig rupturierten Membranen Wir untersuchten Amnionmembranen von 10 Frauen mit normalen Schwangerschaften und Entbindungen am Termin und die von 10 Frauen mit normalen Schwangerschaften und vorzeitigem Blasensprung als „matched pairs“.

In den Membranen wurden die Neutralzucker, Hexosamine, Neuraminsäuren, Uronsäuren, DNA, RNA, Cholesterol, Phospholipide, Calzium, Magnesium, Natrium und Kalium analysiert. Der Gehalt an Kohlen- wasserstoffen differierte in beiden Gruppen nicht signifikant. Das bedeutet gleichzeitig, daß der Gehalt an Glykoproteinen, Glykosaminoglykanen oder Glykolipiden in der Gruppe mit vorzeitigem Blasensprung unverändert ist. Die DNA- und RNA-Menge war in beiden Gruppen ähnlich, ebenso die Konzentration anderer Zellkomponenten wie Cholesterol und Phospholipide. Statistisch signifikante Unterschiede zwischen den beiden Gruppen gab es hinsichtlich der Calzium- und Magnesiumkonzentrationen. Der Calziumgehalt betrug $0,32 \pm 0,7 \mathrm{mg} / 100 \mathrm{mg}$ Protein in der Kontrollgruppe vs. $0,24 \pm 0,07 \mathrm{mg} / 100 \mathrm{mg}$ Protein 
$(p<0.05)$ in der Gruppe mit vorzeitigem Blasensprung. Der Magnesiumgehalt lag bei $0,30 \pm 0,19 \mathrm{mg} /$ $100 \mathrm{mg}$ Protein in der Kontrollgruppe und bei 0,15 $\pm 0,04 \mathrm{mg} / 100 \mathrm{mg}$ Protein $(\mathrm{p}<0,05)$ in der Blasensprunggruppe. Möglicherweise sind niedrige Calzium- und Magnesiumspiegel in Amnionzellmembranen für den Energiestoffwechsel sowie verschiedene Enzymfunktionen ungünstig und spielen somit eine Rolle in der Pathogenese des vorzeitigen Blasensprungs. Dies sollte näher untersucht werden.

Schlüsselwörter: Amnionmembranen, Calzium, Magnesium, vorzeitiger Blasensprung.

\section{Résumé}

Étude des membranes amniotiques humaines normales et rompues prématurement: calcium et magnesium bas dans les membranes rumpues prématurement

Les membranes amniotiques de dix femmes avec accouchements et grossesses de terme normal ont été appariées avec les membranes provenant de fix femmes avec grossesses normales et une rupture prématurée des membranes (PROM) à terme.

On a analysé les membranes pour les sucres neutres les hexosamines, l'acide sialique, l'acide uronique, le DNA, le RNA, le cholestérol, les phospholipides, le calcium, le magnésium, le sodium et le potassium. L'analyse des hydrates de carbone des deux groupes n'a pas mis en évidence de différence significative ce qui implique que dans le groupe avec PROM il n'y a pas d'altération des glycoprotéines, de glycosaminoglycanes ni des glycolipides. Les seules différences sta- tistiquement significatives entre les deux groupes de membranes amniotiques sont au niveau des concentrations en calcium et en magnésium. La concentration en calcium dans le groupe témoin est de $0,32 \pm 0,7$ $\mathrm{mg} / 100 \mathrm{mg}$ de protéine versus $0,24 \pm 0,07 \mathrm{mg} / 100 \mathrm{mg}$ de protéine $(p<0,05)$ dans le groupe avec PROM. La teneur en magnésium est de $0,30 \pm 0,19 \mathrm{mg} / 100 \mathrm{mg}$ de protéine dans le groupe témoin versus $0,15 \pm 0,04$ $\mathrm{mg} / 100 \mathrm{mg}$ de protéine $(\mathrm{p}<0,05)$ dans le groupe avec PROM. Dans la pathogénèse des PROM peuvent jouer un rôle de possibles effets métaboliques des faibles taux de calcium et de magnésium dans les cellules des membranes amniotiques avec PROM qui peuvent effecter le métabolisme générateur d'énergie et les fonctions de divers enzymes. On devrait les évaluer davantage.

Mots-clés: Calcium, magnésium, membrane amniotique, rupture prématurée.

Acknowledgements: This study was supported in part by a grant from the Chief Scientist, Ministry of Health, Israel, and by the Posnack Family Foundation of Hollywood, Fort Lauderdale Florida, U.S.A.

\section{References}

[1] ANAST CS, DW GARDNER: Magnesium metabolism. In: BRONNER F, JW COBURN (eds): Disorders of Mineral Metabolism. Vol III Academic Press 1981

[2] Artal R, JR Sokol, M Newman, AH Burstein, J STOJKov: The mechanical properties of prematurely and non-prematurely ruptured membranes. Methods and preliminary results. American Journal of Obstetrics and Gynecology 125 (1976) 655

[3] BoAs NF: Method for the determination of hexosamines in tissues. Journal of biological Chemistry 204 (1953) 553

[4] Bou-Resli, MN, NS Al-ZaID, MEA Ibrahim: Full term and prematurely ruptured fetal membranes. An ultrastructural study. Cell Tissue Research 220 (1981) 263

[5] BRown AH: Determination of pentose in the presence of large quantities of glucose. Archives Biochemistry 11 (1946) 269

[6] BURTON K: A study of the conditions and mechanism of the diphenylamine reaction for the colorimetric estimation of deoxyribonucleic acid. Biochemical Journal 62 (1956) 315
[7] ChEn PS, TY Toribara, H Warner: Microdetermination of phosphorus Analytical Chemistry 28 (1956) 1756

[8] Cittandini A, D Bossi, FI Wolf, AM Dani: The role of the intracellular $\mathrm{Ca} / \mathrm{Mg}$ ratio in bioenergetic reactions. In: ANGHILERI LJ, AM TUFFETANGHILERI (eds): The Role of Calcium in Biological Systems. Vol 2 Ch 12 C. R. C. Press Incorporated, West Palm Beach, Florida 1982

[9] Conradt A, H Weidinger, H Algayer: Die Bedeutung von Betamimetika und Magnesium für den Schwangerschaftsausgang: I. Reduzierung der Mangelgeburt, sowie der vorzeitigen Amnioruptur und Frühgeburt nach Magnesium-Zusatztherapie. Zeitschrift Geburtshilfe Perinatologie 187 (1983) 127

[10] Dische Z: A new specific color reaction of hexuronic acid. Journal of Biological Chemistry 167 (1947) 189

[11] Folch J, M Lees, GH Sloane-Stanley: A simple method for the isolation and purification of total lipids from animal tissues. Journal of Biological Chemistry 266 (1957) 497 
[12] Jenkins DM, M O'NeIL, M MatTar, VM France, BL HSI, WP FaULK: Degenerative changes and detection of plasminogen in foetal membranes that ruptured prematurely. British Journal of Obstetrics and Gynecology 90 (1983) 841

[13] Kidroni G, MJ SPIRo, RG SPIRo: Studies of thyroid cell surface glycoproteins: Isolation of plasma membranes and characterization of carbohydrate units. Archieves Biochemistry and Biophysics 203 (1980) 151

[14] Killholma P, R Gronroos, P ErkKola, P PaKARINEN, V NANTO: The role of calcium, copper and zinc in preterm delivery and premature rupture of fetal membranes. Gynecological and $\mathrm{Ob}-$ stetrical Investigation 17 (1984) 194

[15] KING BF: Cell surface specializations and intercellular junctions in human amniotic epithelium: An electron microscopic and freeze-fracture study. Anatomical Record 203 (1982) 73

[16] Kirkpatrick C, C Boggaert, J VANsande, F RoDESCH: Control of adenosine-3', 5'-monophosphate level in human amnion by prostaglandin $\mathrm{E} 1$ and isoproterenol. American Journal of Obstetrics and Gynecology 141 (1981) 195

[17] LOWRY OH, NJ ROSEBROUGH, AL FARR, RJ RANDALL: Protein measurement with the Folin phenol reagent. Journal of Biological Chemistry 193 (1951) 265

[18] Mead PB: Management of the patient with premature rupture of the membranes. Clinical Perinatology 7 (1980) 243

[19] NAEYE RL, AC PETERS: Causes and consequences of premature rupture of foetal membranes. Lancet I (8161) (1980) 192

[20] Olson DM, MA Opavski, JRG Challis: Prostaglandin synthesis by human amnion is dependent upon extracellular calcium. Canadian Journal of Physiology and Pharmacology 61 (1983) 1089

[21] PARK JT, MJ Johnson: A submicrodetermination of glucose. Journal of Biological Chemistry 181 (1949) 149

[22] Parry-Jones E, S Priya: A study of the elasticity and tension of foetal membranes and of the relation of the area of the gestational sac to the area of the uterine cavity. British Journal of $\mathrm{Ob}-$ stetrics and Gynecology 83 (1976) 205

[23] Regan JA, S ChaO, LS James: Premature rupture of membranes, preterm delivery and group B streptococcal colonization of mothers. American Journal of Obstetrics and Gynecology 141 (1981) 184

[24] Romero R, M MAZor: Infection and preterm labor. Clin Obstet Gynecol 31 (1988) 553
[25] Ron M, U Beller, J Ori, M Ben-David, Z Palti: Maternal and fetal serum prolactin levels in cases of premature rupture of membranes. Acta Obstetrica Hynecologica Scandinavica 62 (1983) 37

[26] Sagawa N, JE Bleasdale, GC Di Renzo: The effect of polyamines and aminoglycosides on phosphatidylinositol-specific phospholipase from human amnion. Biochimica Biophysica Acta 752 (1983) 153

[27] Schmidt W, K Pfaller, H Schwarzfurtner: Licht- und Elektronenmikroskopische Untersuchungen an den Eihäuten des Menschen. I. Amnion und Zwischenschicht. Zentralblatt für $\mathrm{Gy}$ näkologie 104 (1982) 385

[28] Schwartz AL, CS Forster, PA SMith, GC LigGINS: Human amnion metabolism. I. In bitro maintenance. American Journal of Obstetrics and Gynecology 127 (1977) 470

[29] SKInNeR SJM, GA CAMPos, GC Liggins: Collagen content of human amniotic membranes: Effect of gestation length and premature rupture. Obstetrics and Gynecology 57 (1981) 487

[30] SKINNER SJM, GC LIGGINS: Glycosaminoglycans and collagen in human amnion from pregnancies with and without premature rupture of membranes. Journal of Developmental Physiology 3 (1981) 111

[31] SPIRo RG: Analysis of sugars found in glycoproteins biosynthesis: Studies on thyroglobulin. Journal of Biological Chemistry 241 (1977) 1271

[32] SPIRO MJ: Presence of a glucuronic acid-containing carbohydrate unit in human thyroglobulin. Journal of Biological Chemistry 252 (1977) 5424

[33] SVENNERHOLM L: Quantitative estimation of sialic acid. II. A colorimetric resorcinol-hydrochloric acid method. Biochimica Biophysica Acta 24 (1957) 604

[34] WARREN L: The thiobarbituric acid assay of sialic acid. Journal of Biological Chemistry 234 (1959) 1971

[35] Zlatkis A, B ZaK, AJ BoyLE: A new method for the direct determination of serum cholesterol. Journal of Laboratory and Clinical Medicine 41 (1953) 486

Received September 29, 1989. Accepted October 16, 1989.

Moshe Ron, M. D.

Department of Obstetrics \& Gynecology

Hadassah University Hospital

Mount Scopus, P. O. Box 24035

Jerusalem, 91240

Israel 